\title{
37. IGNEOUS AND METASEDIMENTARY BASEMENT LITHOFACIES OF THE QUEENSLAND PLATEAU (SITES 824 AND 825) ${ }^{1}$
}

\author{
David A. Feary, ${ }^{2}$ David C. Champion, ${ }^{3}$ Robert J. Bultitude, ${ }^{4}$ and Peter J. Davies ${ }^{5}$
}

\begin{abstract}
Queensland Plateau acoustic basement was penetrated by rotary drilling at Sites 824 and 825, to the west and east of Holmes Reef respectively, on the western Queensland Plateau. Despite poor recovery $(5 \%-13 \%)$, the lithologies recovered are of considerable importance as they represent the only basement samples ever obtained from one of the largest marginal plateaus in the world. Altered and deformed metasedimentary rocks form the dominant basement component at both sites. In addition, drilling at Site 824 intersected an assemblage of relatively undeformed intermediate dike rocks, intercalated with the metasediments.

Compositionally, metasediments from both sites are essentially identical and consist predominantly of a detrital quartzofeldspathic assemblage of quartz, feldspar, minor finely crystalline igneous rock fragments, and abundant secondary muscovite/sericite, chlorite, calcite, and rhombs of dolomite. Site 825 contains foliated and indurated metasandstone and metasiltstone that display a poorly to moderately developed cleavage in finer-grained lithologies and very poorly developed anastomosing dissolution cleavage in coarser-grained rocks. By contrast, metasediments at Site 824 are low-grade quartz-muscovite-feldspar schists. Original sedimentary lamination is poorly preserved as a result of overprinting by a well-developed bedding parallel cleavage, together with at least one, and possibly two, cross-cutting cleavages that produced crenulation textures.

The igneous rocks recovered from Site 824 are strongly altered, finely to very finely crystalline rocks of granodioritic to tonalitic composition. The primary mineralogical assemblage is dominated by plagioclase, with subordinate quartz and minor opaques. Alteration is pervasive to the extent that all original ferromagnesian mineral grains and reaction rims have been altered, with extensive development of secondary calcite, chlorite, epidote, opaques, and muscovite/sericite.

The characteristics of the basement lithologies display strong similarities with the Hodgkinson Formation, a major element of the extensive Ordovician to Devonian Hodgkinson Province of northern Queensland. The predominantly Devonian Hodgkinson Formation, which is present on the Australian mainland immediately to the west of the Queensland Plateau drill sites, consists of a thick, monotonous, cleaved graywacke/siltstone/shale/slate succession, with many graywacke beds that contain turbiditic structures. This unit is locally cut by late Paleozoic-early Mesozoic dike swarms, most of which have been extensively altered, and some of which closely resemble the intrusive igneous assemblage recovered at Site 824 .

Drilling at Sites 824 and 825 confirms earlier suggestions that the Tasman Fold Belt is much wider than its outcrop width on the Australian mainland, and indicates that the entire Queensland Plateau basement may be composed of similar rocks. By analogy with the Hodgkinson Formation on the mainland, it is likely that the Queensland Plateau basement metasediments were deposited in a deep marine, extensional back-arc basin environment in the Devonian. Burial and deformation in the latest Devonian or early Carboniferous produced a pervasive slaty cleavage parallel or at a low angle to bedding. Later deformations resulted in crenulation cleavage and kink bands. The igneous dike assemblage was probably intruded in the late Paleozoic or early Mesozoic. Late Paleozoic to earliest Cenozoic uplift and erosion produced a peneplaned surface on which extensive middle and late Cenozoic carbonate reefs developed.
\end{abstract}

\section{INTRODUCTION}

Although the Queensland Plateau is the largest marginal plateau on the Australian continental margin, and one of the largest in the world, information concerning the nature of the basement on which extensive Cenozoic carbonate build-ups have developed has been largely restricted to inferences based upon seismic reflection and refraction studies. The igneous and metasedimentary rocks recovered from Sites 824 and 825 are the first samples recovered from Queensland Plateau acoustic basement.

Prior to drilling by ODP, an extensive grid of multichannel reflection seismic data collected by the Australian Bureau of Mineral Resources (BMR) (now the Australian Geological Survey Organisation) as part of the BMR Continental Margins Survey, together with more restricted airborne magnetic and seismic reflection and refraction studies, formed the basis for speculation concerning the nature and history of the Queensland Plateau basement. Seismic data indi-

\footnotetext{
${ }^{1}$ McKenzie, J.A., Davies, P.J., Palmer-Julson, A., et al., 1993. Proc. ODP, Sci. Results, 133: College Station, TX (Ocean Drilling Program).

${ }^{2}$ Division of Marine Geosciences and Petroleum Geology, Australian Geological Survey Organisation (formerly Bureau of Mineral Resources), Canberra, Australia.

${ }^{3}$ Department of Geology, Australian National University, Canberra, Australia

${ }_{5}^{4}$ Queensland Department of Minerals and Energy, Brisbane, Australia.

${ }^{5}$ Department of Geology and Geophysics, University of Sydney, Sydney, Australia.
}

cate that the present-day surface morphology of the Queensland Plateau, which forms a roughly triangular bathymetric feature tilted gently to the northeast, closely reflects the geometry of underlying acoustic basement (Mutter, 1977; Taylor, 1977). Mutter and Karner (1980) concluded that this outline resulted partly from the geometry of continental rifting and break-up during the Cretaceous and earliest Tertiary, when the Queensland Plateau became separated from the Australian craton by rift troughs underlain by thinned and deeply subsided continental crust (the Queensland and Townsville troughs; see Fig. 1A), and partly by a Paleocene to Eocene episode of seafloor spreading, when the Coral Sea Basin (Fig. 1A) opened to form the northeastern margin of the Queensland Plateau.

Analysis of seismic refraction data, together with the observation that Paleozoic Tasman Fold Belt rocks along the Queensland coast outcropped over a relatively narrow zone, compared to the much broader New England and Lachlan Fold Belt components of the Tasman Fold Belt farther south, lead to speculation that Queensland Plateau basement is composed of Paleozoic Tasman Fold Belt rocks (Ewing et al., 1970). In addition, Mutter (1977) used the BMR Continental Margins Survey seismic data to map the basement topography and showed that it forms broad north-south-trending elevations and depressions, and inferred that these reflect Tasman Fold Belt structural trends. The presence of steeply inclined reflectors, truncated at the acoustic basement surface, on some reflection seismic lines were inferred to represent steeply dipping Tasman Fold Belt 

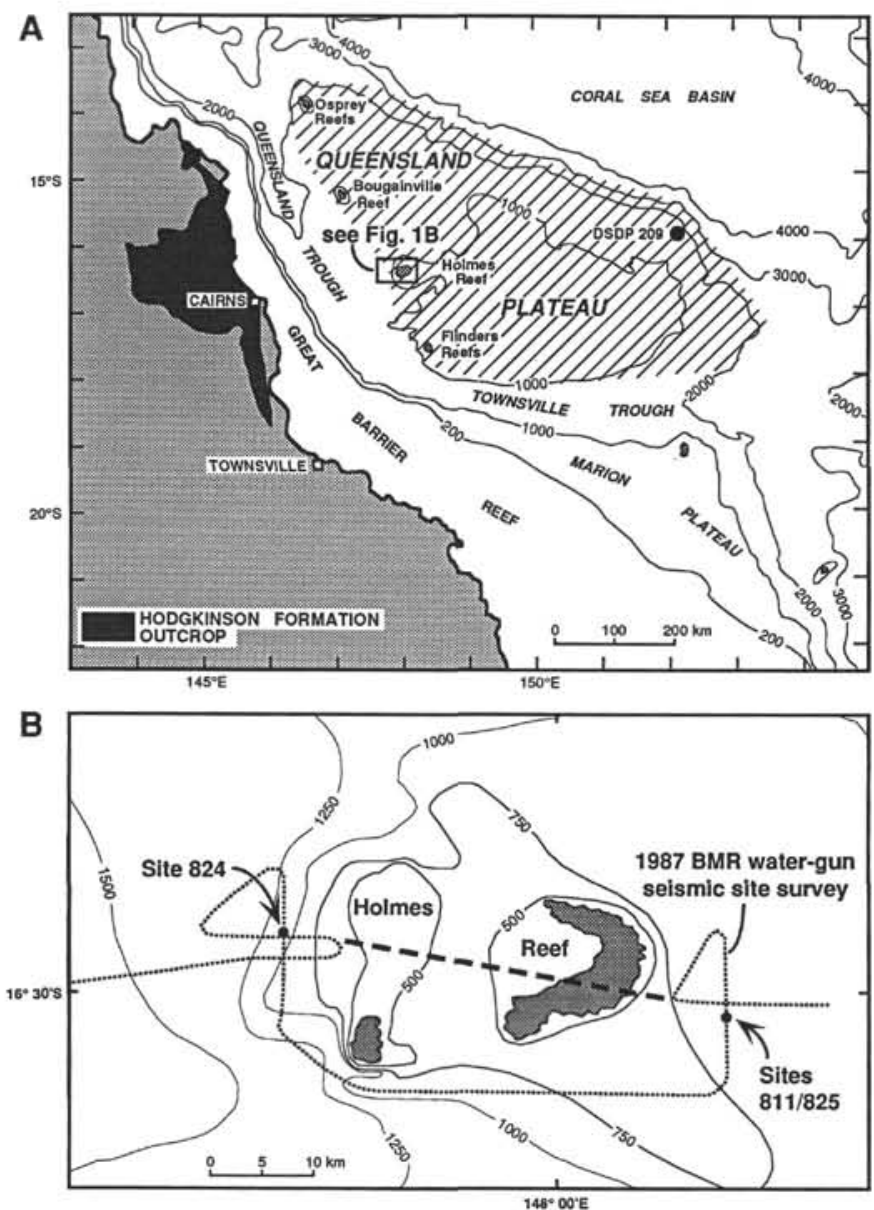

Figure 1. A. Map showing the major physiographic elements of the northeastern Australian margin. The extent of Hodgkinson Formation outcrop on the Australian mainland (after Bultitude et al., 1990) is also shown. Bathymetry in meters. B. Holmes Reef area on the western margin of the Queensland Plateau, together with the location of Sites 824 and 825 and site-survey seismic tracks. Heavy dashed line connecting the site-survey grids indicates the line of the schematic section shown in Figure 2. Bathymetry in meters.

metasediments (Mutter, 1977; Mutter and Karner, 1978). Therefore, although the outline of the plateau reflects Cretaceous and earliest Tertiary continental margin rifting and seafloor spreading, structural trends within the plateau basement are consistent with much older Tasman Fold Belt trends.

Seismic reflection data show that Queensland Plateau acoustic basement consists of planated fault blocks (Fig. 2), with the planated surface reflecting Cretaceous to Eocene or Oligocene subaerial exposure and erosion. The sequence recovered from DSDP 209 (Burns, Andrews, et al., 1973; see Fig. 1A), on the northeastern margin of the Queensland Plateau, together with material recovered during Leg 133 (Davies, McKenzie, Palmer-Julson, et al., 1991), shows that following the early Eocene, the planated surface was progressively submerged and overlain initially by shallow marine carbonate and siliciclastic sediments, and then by deeper-water pelagic sediments. Many researchers have noted that reefal build-ups on the Queensland Plateau grew from basement highs (e.g., Falvey, 1972; Falvey and Taylor, 1974; Mutter, 1974; Davies et al., 1989), and Mutter (1977) showed that the distribution of Cenozoic and modern reefs overlying basement coincided with elevated basement topography. This correspondence is most striking along the western margin of the Queensland Plateau, where a linear reef trend (Flinders, Holmes, Bougainville, and Osprey reefs; see Fig. 1A) has developed on the upthrown edge of rotated and planated fault blocks.

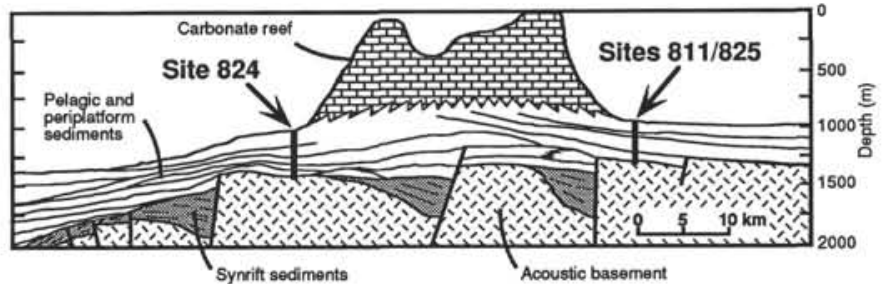

Figure 2. Schematic section showing Sites 824 and 825 . The line of section follows site-survey seismic tracks in the vicinity of the sites, but cuts across Holmes Reef (dashed line in Fig. 1B) between the sites. Geology is based on water-gun seismic data (Feary et al., 1990). Note the planated basement and early syn-rift surface on which the sedimentary sequences were deposited.

The objective of Leg 133 was to gain a detailed understanding of the factors that controlled the evolution of the carbonate platforms and adjacent troughs of northeastern Australia. Site 824, on the upper slope immediately west of Holmes Reef (Fig. 1), was sited to study slope processes in an exclusively carbonate environment and to determine the influence of sea level, paleoceanography, and paleoclimate as controls on Pliocene-Pleistocene periplatform sediment supply into the Queensland Trough. Sites 811/825, immediately east of Holmes Reef on the Queensland Plateau (Fig. 1), were sited to evaluate the influence of sea level and paleoclimate on periplatform sedimentation within a purely carbonate environment. A subsidiary aim at both these sites was to recover samples of acoustic basement.

\section{QUEENSLAND PLATEAU BASEMENT DRILLING}

Sites 824 and 825 are located on different fault blocks, to the west and east of Holmes Reef, respectively (Fig. 2). Initially, Leg 133 operational plans included drilling to basement at Site 811. However, the need to allow adequate time to ensure that the highest priority targets were drilled meant that Site 811 drilling was terminated once the limit of extended core barrel (XCB) drilling was reached, still some $60 \mathrm{~m}$ above basement. As a result, initial penetration of Queensland Plateau basement occurred at Site 824, in $1001 \mathrm{~m}$ water depth to the west of Holmes Reef. The limit of XCB-drilling was reached at 377 mbsf (meters below seafloor) in Hole 824A. Rotary core barrel (RCB) drilling penetrated basement at $407 \mathrm{mbsf}$ in Hole $824 \mathrm{C}$ and at $406 \mathrm{mbsf}$ in Hole $824 \mathrm{D}$, sited $25 \mathrm{~m}$ apart. Although some $25 \mathrm{~m}$ of penetration into basement was achieved at both drill holes, difficulties in recovering samples using the RCB drilling technique resulted in core recovery of only $\sim 5 \%$ in both holes. Basement samples recovered from Hole $824 \mathrm{C}$ consisted of a mixed suite of low-grade quartz-muscovite-feldspar schists and strongly altered, finely crystalline, intermediate igneous rocks (see descriptions below). The entire recovery from Hole $824 \mathrm{D}$ consisted of finely crystalline igneous rocks.

At the conclusion of drilling at Site 824, sufficient time remained to attempt to sample both basement and the sedimentary section immediately overlying basement to the east of Holmes Reef, which had been missed during drilling at Site 811. Accordingly, RCB drilling of Hole 825B, at the same location as Site 811 in $939 \mathrm{~m}$ water depth, reached basement at $453 \mathrm{mbsf}$. Drilling penetrated $13 \mathrm{~m}$ into basement, although again, with relatively poor sample recovery rates (13\%). Basement samples at Site 825 are all foliated and indurated quartzofeldspathic metasandstones and metasiltstones (see descriptions below).

\section{BASEMENT LITHOSTRATIGRAPHY}

Altered and deformed metasedimentary rocks form the dominant basement component at both sites, although at Site 824, the rocks are of considerably higher metamorphic grade (low-grade schists) than the well-indurated metasandstones and metasiltstones at Site 825. In addi- 


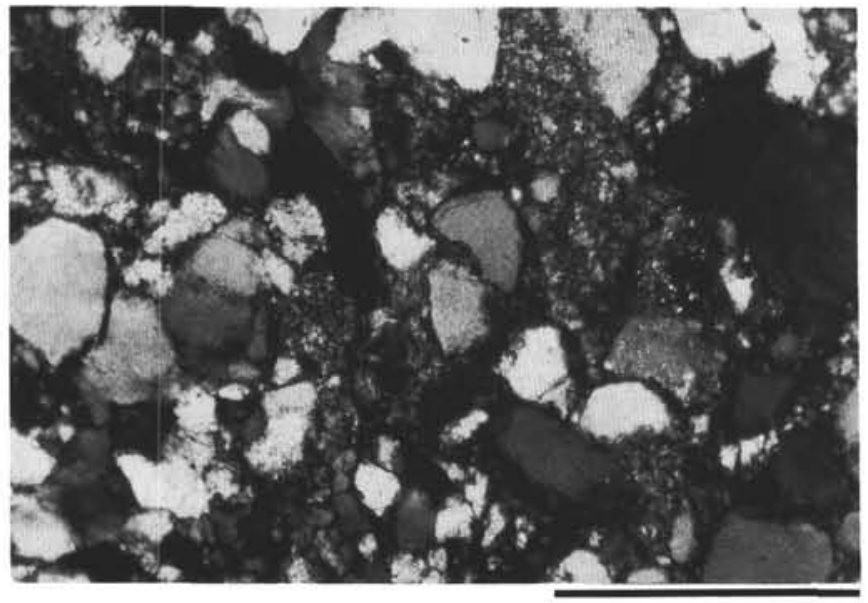

Figure 3. Photomicrograph of Sample 133-825B-9R-1, 7-8 cm, showing poorly sorted grains of quartz, feldspar, and igneous rock fragments within an essentially undeformed, coarse-grained metasandstone. Scale bar $=2.5 \mathrm{~mm}$ long.

tion, Holes $824 \mathrm{C}$ and $824 \mathrm{D}$ intersected an assemblage of intermediate intrusive igneous lithologies, intercalated with the metasediments.

\section{Metasedimentary Lithofacies}

The well-indurated metasandstones and metasiltstones that form the basement at Site 825 are composed of a moderately to poorly sorted detrital assemblage of quartz $(\sim 40 \%)$, feldspar $(\sim 30 \%)$, and finely crystalline igneous rock fragments $(\sim 20 \%)$, together with trace hornblende, biotite, muscovite, apatite, and zircon grains, and matrix (Fig. 3). Maximum grain size ranges from silt to coarse sand size, with deformation effects varying depending on grain size. In the coarsestgrained samples, the only deformation effect is a very poorly developed anastomosing dissolution cleavage, whereas finer-grained sandstone and siltstone have a moderately- to well-developed pervasive cleavage parallel to the original sedimentary lamination. Chlorite, sericite, and indeterminate iron-stained clay fill interstices in the coarser-grained sandstones, whereas the original clay matrix of the finer-grained lithologies has been largely altered to a secondary mineral assemblage of muscovite/sericite, chlorite, calcite, opaque grains, and scattered dolomite rhombs. Feldspar grains are moderately to pervasively sericitized. Quartz and calcite veins are common in all lithologies. An original sedimentary lamination is the only sedimentary structure present, although the poor recovery and small sample size would preclude identification of large structures.

The metasedimentary component at Site 824 consists of low-grade quartz-muscovite-feldspar schist (Fig. 4). The original sedimentary layering is poorly preserved, although it is possible to determine that the dominant foliation is parallel to the sedimentary lamination. At least one, and possibly two cleavages cross-cut the dominant beddingparallel foliation to produce kinks and crenulation structures (Fig. 5). As is the case with the less-deformed metasediments at Site 825, metamorphic effects are least-developed in the coarser-grained lithologies at Site 824. Recrystallization appears virtually complete in the finest-grained schists, whereas an original detrital assemblage, identical to the detrital assemblage in the metasediments at Site 825, is present in the coarser lithologies. In some of the coarsest-grained schists, augen-shaped quartz and feldspar grains have well-developed secondary "tails." Secondary chlorite, opaque grains, and dolomite rhombs are preferentially concentrated in muscovite-rich layers, presumably representing originally finer-grained layers.

The uppermost $40 \mathrm{~cm}$ of basement recovered in Hole $824 \mathrm{C}$ is deeply weathered, mottled orange to brown regolith that consists of large (up to $5 \mathrm{~cm}$ ) clasts (probably originally schist), within an indeterminate iron- and manganese-stained matrix.

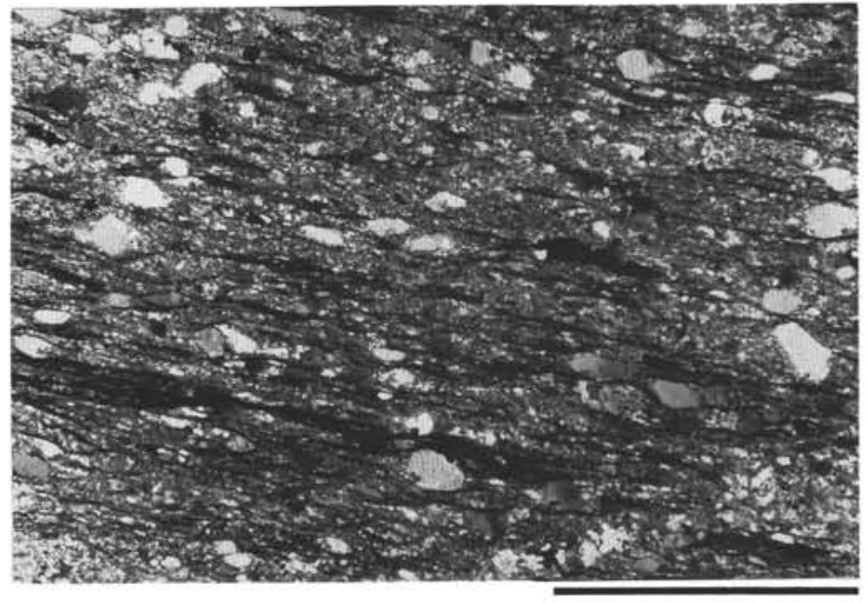

Figure 4. Photomicrograph of Sample 133-824C-19R-1, 31-33 cm, showing texture of a coarse-grained, quartz-muscovite-feldspar schist. The beddingparallel schistosity is less well developed in these coarser-grained rocks, with abundant original detrital quartz and feldspar grains still present. Scale bar = $2.5 \mathrm{~mm}$ long.

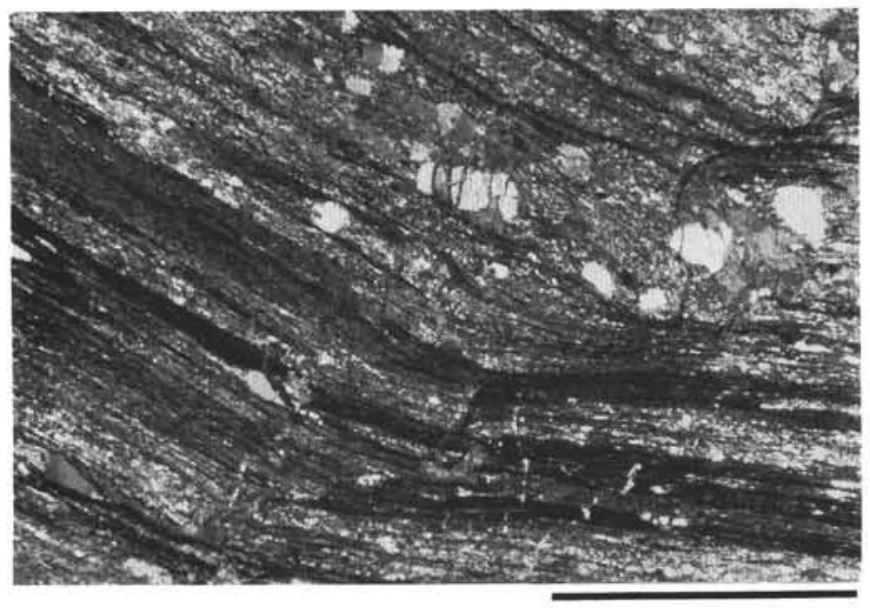

Figure 5. Photomicrograph of Sample 133-824C-18R-1, 100-102 cm, showing a kink band within a layered quartz-muscovite-feldspar schist. Note the betterdeveloped foliation within finer grained layers. Scale bar $=2.5 \mathrm{~mm}$ long.

\section{Igneous Lithofacies}

The igneous rocks in Holes $824 \mathrm{C}$ and $824 \mathrm{D}$ are strongly altered, fine to very finely crystalline, structureless, gray-green microgranodioritic to microtonalitic rocks. Although compositionally uniform, the igneous lithologies can be subdivided into two textural groups as follows:

1. Sparsely porphyritic, fine to very finely crystalline intermediate rocks (133-824C-18R igneous samples; all 133-824D-10R samples; see Appendix). This rock type consists of sparse $(<2 \%)$ phenocrysts of euhedral to subhedral, albite-twinned, slightly zoned plagioclase (up to $3 \mathrm{~mm}$ in size); irregular and embayed quartz (up to $2 \mathrm{~mm}$ ); and very irregular opaques, in some cases with corroded interiors; within a very finely crystalline ( $\leq 0.5 \mathrm{~mm}$; commonly $<0.2 \mathrm{~mm}$ ) groundmass (Fig. 6). Identifiable groundmass minerals include the phenocryst assemblage, together with acicular apatite. In some cases, grouping of phenocrysts has produced a glomeroporphyritic texture. No primary ferromagnesian minerals are present as a result of the pervasive alteration (see below), 
2. Nonporphyritic, finely crystalline intermediate rocks (all 133824D-9R igneous samples; see Appendix). This rock type consists of an equigranular assemblage of plagioclase, quartz, and accessory apatite and opaques (Fig. 7). Plagioclase is the predominant constituent, occurring as generally sausseritized euhedral to subhedral laths up to $7 \mathrm{~mm}$ long, with no preferred orientation direction. Normal zoning is locally evident. Quartz is a subordinate and generally interstitial component that exhibits undulose extinction and minor subgrain development. Accessory apatite occurs as elongate acicular crystals, often locally associated with opaques. Opaques are irregular to subhedral shaped and are probably of both primary and secondary origin. Again, primary ferromagnesian minerals are absent as a consequence of the pervasive alteration. As well as being texturally distinct from the porphyritic assemblage, these rocks are also slightly coarser-grained and more altered.

The pervasive and ubiquitous alteration of these intermediate igneous rocks is reflected by the presence of abundant calcite and chlorite, lesser epidote and muscovite/sericite, and irregular to subhedral opaques. Calcite occurs as irregular and linear veins up to 3 $\mathrm{mm}$ wide; as individual and irregular groups of crystals throughout the groundmass; and surrounding quartz and other secondary grains, presumably replacing reaction rim minerals. In some cases, chlorite probably occurs as a pseudomorph after amphibole, and similarly, some lozenge-shaped opaque grains probably occur after amphibole or sphene. Although very strongly altered, original igneous textures are preserved, and no deformation structures are evident.

Neither the drilling results nor existing seismic data permit any unequivocal determination of the relationship between the metasedimentary and igneous components of the basement. However, the profound difference between the relatively undeformed igneous assemblage and the moderately to considerably deformed metasediments suggests that the igneous phase represents later intrusion into an already deformed metasedimentary terrain, presumably as dikes. One sample (133-824D-9R-1, 2-5 cm) contains a contact between strongly deformed metasediment and very finely crystalline, apparently undeformed, nonporphyritic igneous rock. This contact is irregular, cross-cutting both lithological and structural surfaces in the metasediments, and clearly post-dates sediment metamorphism and deformation. It is not possible to determine whether the strongly foliated and finely crenulated metasediment is country rock or an enclave within the intrusive igneous suite; nevertheless, the similarities between this metasediment and other metasediment facies at Site 824 indicate that it is representative of the country rock.

\section{CORRELATION WITH AUSTRALIAN MAINLAND SEDIMENTARY BASINS}

Although recovery of Queensland Plateau basement rocks at Sites 824 and 825 was relatively poor, nevertheless it is possible to make direct comparisons with rocks exposed on the Australian mainland to the west. The Queensland Plateau basement lithologies are comparable to rocks of the Hodgkinson Province, an Ordovician to Devonian supracrustal sequence that outcrops over $75,000 \mathrm{~km}^{2}$ in the northern part of the Paleozoic Tasman Fold Belt (Arnold and Fawckner, 1980; Bhatia, 1985; Bultitude et al., 1987, 1990; see Fig. 1A). In particular, the deformation characteristics and metamorphic grade of the metasedimentary basement lithologies recovered at Sites 824 and 825 display strong similarities with lithologies of the Hodgkinson Formation, the major component of the Hodgkinson Province, exposed in the Palmer River area. In addition, the Hodgkinson Formation is cut by extensively altered mafic to intermediate dikes, some of which are similar to the igneous rocks recovered from Site 824 . The absence of fossil or any other dating data from the basement samples recovered by drilling means that it is not possible to conclusively assign these rocks to the Hodgkinson Formation. Nevertheless, we consider that the strong similarities between the recovered basement samples and

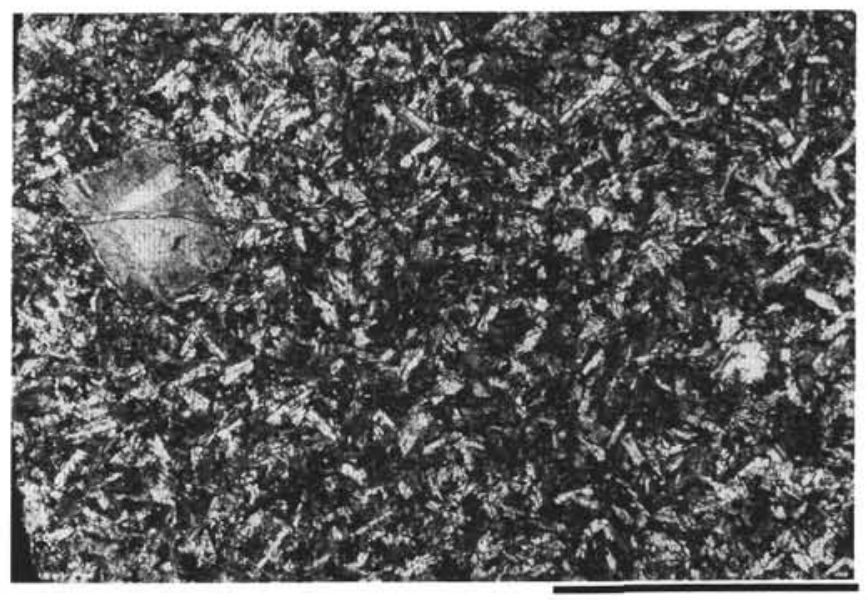

Figure 6. Photomicrograph of Sample 133-824D-10R-1, 2-4 cm, showing a large plagioclase phenocryst within a sparsely porphyritic, finely crystalline dike rock. Scale bar $=2.5 \mathrm{~mm}$ long.

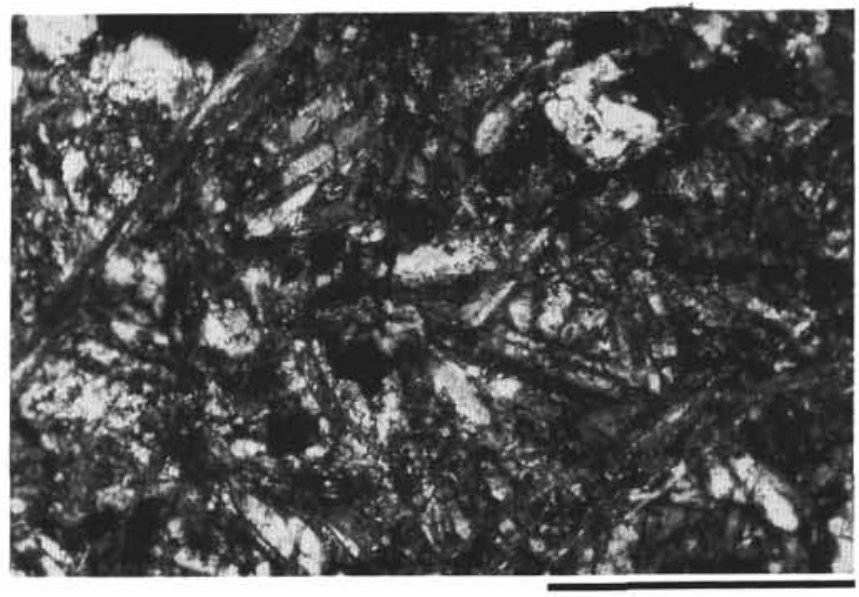

Figure 7. Photomicrograph of Sample 133-824D-9R-1, 68-70 cm, showing nonporphyritic texture within a finely crystalline dike rock. Crystal boundaries appear blurred and indistinct as a result of the pervasive alteration. Scale bar $=0.5 \mathrm{~mm}$ long.

the Hodgkinson Formation, together with the relative proximity (some $220 \mathrm{~km}$ distant) to outcrop of the Hodgkinson Formation on the mainland, makes this inference more likely than alternative suggestions (R.A. Henderson, pers. comm., 1992) that the samples could represent a northern extension of the undated and possibly exotic Shoalwater terrane of the New England Fold Belt (Fergusson et al., 1988,1990 ) which outcrops more than $800 \mathrm{~km}$ to the south-southeast.

The Hodgkinson Formation on the Australian mainland west of the Queensland Plateau is predominantly composed of graywacke, siltstone, and mudstones (and their higher metamorphic grade equivalents) that form thick, monotonous sequences (Amos, 1968; de Keyser and Lucas, 1968; Bultitude et al., 1990). Minor constituents include conglomerate, limestone, chert, and basalt. Volcanogenic detritus is common locally, with the presence of abundant plagioclase and polycrystalline quartz grains indicating a cratonic origin (Bhatia, 1983, 1985; Bultitude et al., 1990). Most researchers have inferred a predominantly deep-water, turbiditic origin (e.g., Arnold and Fawckner, 1980). Sparse fossil evidence (including rare occurrences of limestone clasts containing Frasnian and Famennian conodonts) suggests that the Hodgkinson Formation is mainly Devonian in age, possibly extending back to the latest Silurian (de Keyser and Lucas, 1968; Bultitude et al., 1987, 1990). 
Rocks of the Hodgkinson Province record a complex deformational history with up to five major deformational events of variable intensity currently recognized (Bultitude and Donchak, 1992). Most of these deformations probably occurred in the early to middle Carboniferous, as they affect the Hodgkinson Formation, while the majority pre-date late Carboniferous-late Permian granites.

The Hodgkinson Formation, exposed in a belt up to $\sim 50 \mathrm{~km}$ wide along the coast, is noteworthy because the dominant cleavage in these rocks post-dates the emplacement of Permian granites, many of which contain intensely deformed zones. This cleavage has a north-northwesterly to northwesterly orientation similar to older (pre-late Carboniferous) cleavages that dominate in much of the central and western parts of the province (Bultitude and Donchak, 1992). It pre-dates deposition of the middle Jurassic to Early Cretaceous sediments of the Laura Basin succession and most probably developed during a late Permian-early Triassic deformational event (Bultitude and Champion, 1992).

\section{DISCUSSION AND CONCLUSIONS}

The basement lithologies recovered at Sites 824 and 825 represent the only samples ever recovered from one of the largest marginal plateaus in the world. However, although these drilling results provide important evidence of the nature of Queensland Plateau basement, Sites 824 and 825 are only $43 \mathrm{~km}$ apart on the western margin of the plateau, and accordingly, it is necessary to be cautious when extrapolating these results over the entire Queensland Plateau area. Results from Sites 824 and 825 confirm earlier suggestions that the Tasman Fold Belt is much wider than its outcrop width on the Australian mainland (Ewing et al., 1970; Mutter, 1977; Mutter and Karner, 1978), and that it extends at least a farther $220 \mathrm{~km}$ as slightly thinned continental crust beneath the Queensland Trough to Site 825 (Fig. 1A). Furthermore, the conclusion that the structural "grain" of Queensland Plateau basement reflects Tasman Fold Belt structural trends (Mutter, 1977) and the observation of truncated, steeply dipping reflectors within basement (Mutter and Karner 1978) both suggest that the entire Queensland Plateau is underlain by similar rocks, extending the width of the Tasman Fold Belt some $450 \mathrm{~km}$ farther east from Site 825 (Fig. 1A).

The data from Sites 824 and 825 , together with information describing mainland Queensland rock assemblages (Henderson, 1980, Arnold and Fawckner, 1980, Bultitude et al., 1987, 1990), permit a speculative geological history for the Queensland Plateau basement. A thick quartzofeldspathic flysch sequence was deposited in a deep-marine environment during the Devonian. The mineralogy, geochemistry, and isotope chemistry of these sediments are consistent with derivation from rocks similar to the Proterozoic supracrustal rocks exposed immediately to the west and north of the Tasman Fold Belt in northern Queensland (Bhatia, 1981, 1983, 1985; Champion, 1991). Most interpretations of the evolution of the northern Tasman Fold Belt (of which the Hodgkinson Province forms a significant part) involve the presence of a consuming plate margin for much of the Paleozoic (Henderson, 1980, 1987; Day et al., 1983). However, no general agreement exists as to the location of the volcanic arc and subduction zone with respect to the Hodgkinson Province. There are conflicting interpretations of the tectonic setting of the Hodgkinson Formation depositional environment at this time, with some authors favoring an active margin environment (Henderson, 1980, 1986; Bhatia, 1983, 1985), although recent data (e.g., Champion et al., 1990) lend weight to the alternative explanation that the environment was an extensional backarc basin (Withnall et al., 1987, 1988; Bultitude et al., 1990; Champion, 1991). Nevertheless, the deformations recorded by the rocks of the Hodgkinson Province most probably represent crustal shortening events or orogenies, each of which was in direct or indirect response to plate interactions and subduction.

Burial and deformation during the latest Devonian or early Carboniferous produced a pervasive slaty cleavage, associated with tight folding and thrusting (Henderson, 1980, Shaw et al., 1987; Bultitude et al., 1990). It is likely that most of the bedding-parallel cleavage visible in the metasediments from Sites 824 and 825 , and particularly well-developed in the finer-grained rocks, can be attributed to this event. Most of the later deformation effects observed in the Queensland Plateau basement samples (e.g., crenulation cleavage and kink bands in schists; cross-cutting veins in both metasediments and igneous rocks) may be attributed to some of the three or four later deformational events identified in Hodgkinson Province rocks on the Australian mainland (Bultitude and Donchak, 1992).

The igneous dike assemblage recovered from Site 824 probably correlates with late Paleozoic igneous activity on the mainland, which resulted in intrusion of numerous felsic to mafic dikes (Henderson, 1980), although a possibility also exists that these may correlate with a later, Cretaceous phase of dike intrusion.

Uplift during the late Paleozoic to earliest Cenozoic exposed the faulted Queensland Plateau basement surface to deep erosion, to form an extensive peneplaned surface (Fig. 2). This erosion episode is also represented by the formation of a regolith layer at the basement surface at Site 824. Eocene or Oligocene transgression of the basement surface is represented by a thin, quartzose, bioclastic sandstone/conglomerate immediately overlying basement at Site 824 (Davies, McKenzie, Palmer-Julson, et al., 1991). Subsequently, carbonate deposition throughout much of the middle and late Cenozoic produced the thick Queensland Plateau cover sequence.

\section{ACKNOWLEDGMENTS}

We gratefully acknowledge constructive reviews by J.H.C. Bain (Australian Geological Survey Organisation); R.A. Henderson (James Cook University of North Queensland); and S. Stewart (ODP). Feary publishes with permission of the Executive Director, Australian Geological Survey Organisation; and Bultitude publishes with permission of the Chief Government Geologist, Department of Minerals and Energy, Queensland.

\section{REFERENCES $*$}

Amos, B.J., 1968. The structure of the Palaeozoic sediments of the Mossman and Cooktown areas, north Queensland. Aust. J. Earth Sci., 15:195-208.

Arnold, G.O., and Fawckner, J.F., 1980. The Broken River and Hodgkinson Provinces. In Henderson, R.A., and Stephenson, P.J. (Eds.), The Geology and Geophysics of Northeastern Australia. Geol. Soc. Aust., Queensland Div., 175-189.

Bhatia, M.R., 1981. Petrology, geochemistry and tectonic setting of some flysch deposits [Ph.D. dissert.]. Australian National Univ., Canberra.

1983. Plate tectonics and geochemical composition of sandstones. J. Geol., 91:611-627.

1985. Rare earth element geochemistry of Australian Palaeozoic greywackes and mudrocks: provenance and tectonic control. Sediment. Geol., 45:97-113.

Bultitude, R.J., and Champion, D.C., 1992. Granites of the eastern Hodgkinson Province-their field and petrographic characteristics. Queensl. Dep. Res. Indust., Rec., 1992/6.

Bultitude, R.J., Donchak, P.J., 1992. Pre-Mesozoic stratigraphy and structure of the Maytown region. Queensl. Dep. Res. Indust., Rec., 1992/5.

Bultitude, R.J., Donchak, P.J., Domagala, J., Fordham, B.G., and Champion, D.C., 1990. Geology and tectonics of the Hodgkinson Province, north Queensland. Proc. 1990 Pacific Rim Congr., Australas. Inst. Min. Metall., 3:75-81.

Bultitude, R.J., Green, P.M., and Domagala, J., 1987. Revision of the stratigraphy of the southwestern Hodgkinson Province. Queensl. Gov. Min. J., 88:187-191.

Burns, R.E., Andrews, J.E., et al., 1973. Init. Repts. DSDP, 21: Washington (U.S. Govt. Printing Office).

\footnotetext{
Abbreviations for names of organizations and publications in ODP reference lists follow the style given in Chemical Abstracts Service Source Index (published by American Chemical Society).
} 
Champion, D.C., 1991. The felsic granites of far north Queensland [Ph.D. dissert.]. Australian National Univ., Canberra.

Champion, D.C., Chappell, B.W., and McCulloch, M.T., 1990. Granites from the Hodgkinson Province, north Queensland; origin and implications for crustal evolution: isotopic and geochemical evidence. Geol. Soc. Aust. Abstr., 27:17. (Abstract)

Davies, P.J., McKenzie, J.A., Palmer-Julson, A., et al., 1991. Proc. ODP, Init. Repts., 133: College Station, TX (Ocean Drilling Program).

Davies, P.J., Symonds, P.A., Feary, D.A., and Pigram, C.J., 1989. The evolution of the carbonate platforms of northeast Australia. In Crevello, P.D., Wilson, J.L., Sarg, J.F., Read, J.F. (Eds.), Controls on Carbonate Platform and Basin Development. Spec. Publ.-Soc. Econ. Paleontol. Mineral., 44:233-258.

Day, R.W., Whitaker, W.G., Murray, C.G., Wilson, I.H., and Grimes, K.G., 1983. Queensland Geology: A companion volume to the $1: 2,500,000$ scale geological map (1975). Publ._Geol. Surv. Queensl., 383.

De Keyser, K., and Lucas, K.G., 1968. Geology of the Hodgkinson and Laura Basins, north Queensland. Bull.-Bur. Miner. Resour, Geol. Geophys. (Aust.), 84

Ewing, M., Hawkins, L.V., and Ludwig, W.J., 1970. Crustal structure of the Coral Sea. J. Geophys. Res., 75:1963-1972.

Falvey, D.A., 1972. The nature and origin of marginal plateaux and adjacent ocean basins off northern Australia [Ph.D. dissert.]. Univ. of New South Wales, Sydney.

Falvey, D.A., and Taylor, L.W.H., 1974. Queensland Plateau and Coral Sea Basin: structural and time stratigraphic patterns. Bull. Aust. Soc. Explor: Geophysicists, 5:123-126.

Feary, D.A., Pigram, C.J., Davies, P.J., Symonds, P.A., Droxler, A.W., and Peerdeman, F., 1990. Ocean Drilling Program-Leg 133-Northeast Australia safety package. Bur. Miner. Resour. Aust. Rec., 1990/6.

Fergusson, C.L., Henderson, R.A., and Leitch, E.C., 1988. Tectonostratigraphic terranes and subduction complex melange, northern New England Orogen, central Queensland. In Kleeman, J.D. (Ed.), New England Orogen-Tectonics and Metallogenesis. Armidale (Univ. New England), 32-41.

, 1990. Subduction complex melange of the Wandilla terrane, Palaeozoic New England Orogen, central Queensland, Australia. J. Struct. Geol., 12:591-599.

Henderson, R.A., 1980. Structural outline and summary geological history for northeastern Australia. In Henderson, R.A., and Stephenson, P.J. (Eds.),
The Geology and Geophysics of Northeastern Australia. Geol. Soc. Aust. Queensl. Div., 1-26.

- 1986. Geology of the Mt. Windsor subprovince - a Lower Palaeozoic volcano-sedimentary terrane in the northern Tasman Orogenic Zone. Aust. J. Earth Sci., 33:343-364.

, 1987. An oblique subduction and transform faulting model for the evolution of the Broken River Province, northern Tasman Orogenic Zone. Aust. J. Earth Sci., 34:237-249.

Mutter, J.C., 1974. Geophysical results from the Coral Sea: continental margins survey report. Rec. Bur. Miner. Resour, Geol. Geophys. (Aust.), 1973/107.

, 1977. The Queensland Plateau. Bull.—Bur. Miner. Resour., Geol. Geophys. (Aust.), 179.

Mutter, J.C., and Karner, G.D., 1978. Cretaceous taphrogeny in the Coral Sea. Bull. Aust. Soc. Explor. Geophysicists, 9:82-87.

1980. The continental margin off northeast Australia. In Henderson, R.A., and Stephenson, P.J. (Eds), The Geology and Geophysics of Northeast Australia. Geol. Soc. Aust., Queensl. Div., 47-69.

Shaw, R.D., Fawckner, J.F., and Bultitude, R.J., 1987. The Palmerville Fault system: a major imbricate thrust system in the northern Tasmanides, north Queensland. Aust. J. Earth Sci., 34:69-93.

Taylor, L.W.H., 1977. The western Coral Sea: sedimentation and tectonics [Ph.D. dissert.]. Univ. of Sydney, Sydney.

Withnall, I.W., Bultitude, R.J., Lang, S.C., Donchak, P.J., and Hammond, R.L., 1987. Geology and tectonic history of the Palaeozoic Hodgkinson and Broken River Provinces, north Queensland. Proc. 1987 Pacific Rim Congr., Aust. Inst. Min. Metall., 495-498.

Withnall, I.W., Lang, S.C., Jell, J.S., McLennan, T.P.T., Talent, J.A., Mawson, R., Fleming, P.J.G., Law, S.R., Macansh, J.D., Savory, P., Kay, J.R., and Draper, J.J., 1988. Stratigraphy, sedimentology, biostratigraphy, and tectonics of the Ordovician to Carboniferous Broken River Province, north Queensland. Australas. Sedimentol. Group, Field Guide Ser., 5.

Date of initial receipt: 12 March 1992

Date of acceptance: 22 January 1993

Ms 133SR-254

APPENDIX

Samples Examined and Described as Part of This Study

\begin{tabular}{|c|c|c|}
\hline $\begin{array}{l}\text { Core, section, } \\
\text { interval }(\mathrm{cm})\end{array}$ & $\begin{array}{l}\text { Depth } \\
\text { (mbsf) }\end{array}$ & Lithology \\
\hline \multicolumn{3}{|l|}{$133-824 \mathrm{C}$ - } \\
\hline $18 \mathrm{R}-1,39-41$ & 411.89 & Quartz-muscovite-feldspar schist \\
\hline $18 \mathrm{R}-1,57-59$ & 412.07 & Porphyritic intermediate igneous rock \\
\hline $18 \mathrm{R}-1,80-82$ & 412.30 & Porphyritic intermediate igneous rock \\
\hline $18 \mathrm{R}-1,100-102$ & 412.50 & Quartz-muscovite-feldspar schist \\
\hline $18 \mathrm{R}-1,110-112$ & 412.60 & Quartz-muscovite-feldspar schist \\
\hline $19 \mathrm{R}-1,10-13$ & 421.30 & Quartz-muscovite-feldspar schist \\
\hline $19 \mathrm{R}-1,27-29$ & 421.47 & Quartz-muscovite-feldspar schist \\
\hline $19 \mathrm{R}-1,31-33$ & 421.51 & Quartz-muscovite-feldspar schist \\
\hline $19 \mathrm{R}-1,38-40$ & 421.58 & Quartz-muscovite-feldspar schist \\
\hline \multicolumn{3}{|l|}{ 133-824D- } \\
\hline $9 \mathrm{R}-1,2-5$ & 411.52 & Contact between schist and igneous rock \\
\hline $9 \mathrm{R}-1,23-25$ & 411.73 & Equigranular intermediate igneous rock \\
\hline $9 \mathrm{R}-1,35-37$ & 411.85 & Equigranular intermediate igneous rock \\
\hline $9 \mathrm{R}-1,68-70$ & 412.18 & Equigranular intermediate igneous rock \\
\hline $9 \mathrm{R}-1,72-74$ & 412.22 & Equigranular intermediate igneous rock \\
\hline $10 \mathrm{R}-1,2-4$ & 421.22 & Porphyritic intermediate igneous rock \\
\hline $10 \mathrm{R}-1,12-15$ & 421.32 & Porphyritic intermediate igneous rock \\
\hline $10 \mathrm{R}-1,52-55$ & 421.72 & Porphyritic intermediate igneous rock \\
\hline \multicolumn{3}{|l|}{$133-825 \mathrm{~B}-$} \\
\hline $9 \mathrm{R}-1,7-8$ & 453.07 & Coarse-grained metasandstone \\
\hline $9 \mathrm{R}-1,14-16$ & 453.14 & Metasiltstone with fine-grained metasandstone \\
\hline $9 \mathrm{R}-1,48-50$ & 453.48 & Metasiltstone \\
\hline $9 \mathrm{R}-1,74-76$ & 453.74 & Metasiltstone \\
\hline $10 \mathrm{R}-1,16-18$ & 456.86 & Very fine-grained metasandstone \\
\hline $10 \mathrm{R}-1,80-82$ & 457.50 & Very fine-grained metasandstone \\
\hline $10 \mathrm{R}-1,90-93$ & 457.60 & Fine-grained metasandstone \\
\hline $10 \mathrm{R}-1,98-100$ & 457.68 & Fine-grained metasandstone \\
\hline
\end{tabular}

Note: "Interval" refers to distance from the core top to the sample top and bottom, respectively, and "Depth" is the calculated distance from the seafloor to the top of the sample. Depths listed are approximate minimum depths, as samples recovered from a core with poor recovery are assigned depths measured from the core top, with the resoft that actual depths may be up to $9.5 \mathrm{~m}$ greater than those listed. 